\title{
歯科衛生士専門学校生のエイズに対する意識 一講義による意識の変化一
} 廣瀬 晃子 $^{1}$ 石津恵津子 $^{1}$ 小澤 $^{\text {亨司 }^{1}}$ 可児 徳子 $^{1}$

\author{
A Study of Attitude, Behavior and Knowledge regarding AIDS \\ among Dental Hygienist Students \\ - Changing Awareness through Lecture-
}

\section{Akiko HIROSE ${ }^{1}$, Etsuko ISHIZU ${ }^{1}$, Kohji OZAWA ${ }^{1}$ and Tokuko KANI ${ }^{1}$}

We examined the change in awareness, both systematically and continuously, after delivering education regarding acquired immunodeficiency syndrome (AIDS) by lecture mode. The survey subjects were 51 (school A), 49 (school B) and 45 (school C) students who entered one of the three dental hygienist schools in April 1999 and who participated in an investigation on their attitude, behavior and knowledge regarding AIDS in April and February of their first year. We conducted four lectures about AIDS after the first survey at schools A and B (Lecture group).

The following results were demonstrated:

1. In the lecture group and non-lecture group, the students differed in their attitude and behavior, and the number of students who recognized AIDS as a common disease increased.

2. By receiving the lecture, students became afraid of the prevalence of AIDS; they considered that they might conduct dental procedures when they had been infected with HIV; and they believed that it was necessary for them to know whether patients were infected with HIV.

3. The students' knowledge about AIDS increased after education.

It is necessary to conduct follow-up studies to examine whether the students are able to retain a good command of this education.

Key words : Lecture, AIDS, Dental Hygienist Student 講義, エイズ, 歯科衛生士専門学校生

\section{I 緒言}

現在の我が国におけるエイズをめぐる状況は， 爆発的な流行は見られないものの新規の HIV 感 染者やAIDS患者（以下 HIV/AIDS）が毎年増加
している状態である.この様な中, 歯科を受診す る HIV/AIDS も増加していることが報告され （茂木ほか，2000）, 潜在 HIV/AIDSが歯科診療 所に通院している割合も増加していると推測され る。そのため歯科医療従事者はHIV/AIDSに対

1朝日大学歯学部社会口腔保健学講座

${ }^{\prime}$ Department of Community Oral Health, School of Dentistry, Asahi University 
する倫理而での対応，水平感染予防対策，歯科 疾患治療など多くの問題に対処しなければならな い. しかし疄科医療従事者を対象として実施した エイズに関する調査では，道德的な観点から歯科
治療を奉施すべきと考えているにもかかわらず， 治療経験がないことや知識や意識不足, 診療体制 が確保できないなどの理由から，HIV/AIDSの 歯科治療に消極的あるいは治療を拒否する者の存

\section{表 1 エイズに関する意識の質問内容}

一般生活_上の意識

\begin{tabular}{|c|c|c|c|}
\hline \multicolumn{2}{|r|}{ 犋间項目 } & \multicolumn{2}{|c|}{ 選択肢 } \\
\hline Q1 & $\begin{array}{l}\text { エイズという病気をどの様に感じ } \\
\text { るか }\end{array}$ & $\begin{array}{l}\text { (1)関心がない } \\
\text { (3)なんとなく怖い }\end{array}$ & $\begin{array}{l}\text { (2)非常に怖い } \\
\text { (4)怖くない }\end{array}$ \\
\hline Q2 & 日本でエイズは流行すると思うか & $\begin{array}{l}\text { (1)流行しない } \\
\text { (3)流行し徐々に增加 }\end{array}$ & $\begin{array}{l}\text { (2)特定の人で流行 } \\
\text { (4)大流行し蒸発的に増加 }\end{array}$ \\
\hline Q3 & 一般生活で感染する不宛を持つか & $\begin{array}{l}\text { (1)持つ } \\
\text { (3)ほとんどない }\end{array}$ & $\begin{array}{l}\text { (2)多少持つ } \\
\text { (4)全然ない }\end{array}$ \\
\hline Q4 & $\begin{array}{l}\text { 家族が感染したらどのように対応 } \\
\text { するか }\end{array}$ & $\begin{array}{l}\text { (1)別居する } \\
\text { (3)精神的支援をする }\end{array}$ & $\begin{array}{l}\text { (2)特に何もしない } \\
\text { (4)積極的に対処する }\end{array}$ \\
\hline Q5 & $\begin{array}{l}\text { 友人が感染したらどのように対応 } \\
\text { するか }\end{array}$ & $\begin{array}{l}\text { (1)付き合いをやめる } \\
\text { (3)今までどおり付き合う }\end{array}$ & $\begin{array}{l}\text { (2)付き合いを減らす } \\
\text { (4)栍極的に文嗳する }\end{array}$ \\
\hline Q6 & エイズ検香を受けるか & $\begin{array}{l}\text { (1)受けない } \\
\text { (3)機会があれば受ける }\end{array}$ & $\begin{array}{l}\text { (2)必望ならば受ける } \\
\text { (4)积極的に受ける }\end{array}$ \\
\hline Q7 & $\begin{array}{l}\text { 一般生活上での感染艼防知識はあ } \\
\text { ると思うか }\end{array}$ & $\begin{array}{l}\text { (1)全くない } \\
\text { (3)少しある }\end{array}$ & $\begin{array}{l}\text { (2)あまりない } \\
\text { (4)十分ある }\end{array}$ \\
\hline \multicolumn{4}{|c|}{ 菓科業狢_上の意識 } \\
\hline \multicolumn{2}{|r|}{ 筫䦌項目 } & \multicolumn{2}{|c|}{ 選択肢 } \\
\hline Q8 & $\begin{array}{l}\text { 菊科治潦に携わる時感染すること } \\
\text { があると思うか }\end{array}$ & $\begin{array}{l}\text { (1)ある } \\
\text { (3)ほとんどない }\end{array}$ & $\begin{array}{l}\text { (2)多少ある } \\
\text { (4)全然ない }\end{array}$ \\
\hline Q9 & $\begin{array}{l}\text { HIV/AIDS の治療に携わる可能性 } \\
\text { があると思うか }\end{array}$ & $\begin{array}{l}\text { (1)ない } \\
\text { (3)あると思う }\end{array}$ & $\begin{array}{l}\text { (2)ほとんどない } \\
\text { (4)必ずある }\end{array}$ \\
\hline Q10 & $\begin{array}{l}\text { HIV/AIDS が来院してきたらどの } \\
\text { ような気持ちになるか }\end{array}$ & $\begin{array}{l}\text { (1)嫌墨感をもつ } \\
\text { (3)少し意識する }\end{array}$ & $\begin{array}{l}\text { (2)かなり意識する } \\
\text { (4)普段と変わらない }\end{array}$ \\
\hline Q11 & $\begin{array}{l}\text { HIV/AIDS の処㨁を指示されたら } \\
\text { どうするか }\end{array}$ & $\begin{array}{l}\text { (1)指示を拒否する } \\
\text { (3)嫌だが他の忠者と同様に対応 }\end{array}$ & $\begin{array}{l}\text { (2)対応するができれば避ける } \\
\text { (4)意識せずに対応 }\end{array}$ \\
\hline Q12 & $\begin{array}{l}\text { HIV/AIDS が来院した時十分対応 } \\
\text { できると思うか }\end{array}$ & $\begin{array}{l}\text { (1)できない } \\
\text { (3)できると思う }\end{array}$ & $\begin{array}{l}\text { (2)できないと思う } \\
\text { (4)できる }\end{array}$ \\
\hline Q13 & $\begin{array}{l}\text { 勤務する歯科診療所で搒療体制を } \\
\text { 碓保できると思うか }\end{array}$ & $\begin{array}{l}\text { (1)できない } \\
\text { (3)できると思う }\end{array}$ & $\begin{array}{l}\text { (2)できないと思う } \\
\text { (4)できる }\end{array}$ \\
\hline Q14 & 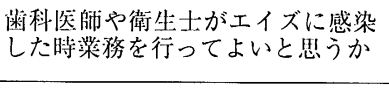 & $\begin{array}{l}\text { (1)行うべきでない } \\
\text { (3)業務内容によって行ってもよい }\end{array}$ & $\begin{array}{l}\text { (2)できるだけ行わないほうがよい } \\
\text { (4)行ってもよい }\end{array}$ \\
\hline Q15 & 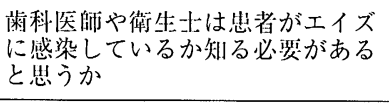 & $\begin{array}{l}\text { (1)知る必要はない } \\
\text { (3)感染予防のため知る必要あり }\end{array}$ & $\begin{array}{l}\text { (2)必ずしも知る必要はない } \\
\text { (4)当然知る必要あり }\end{array}$ \\
\hline Q16 & 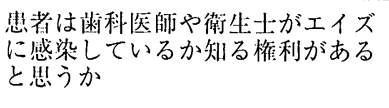 & $\begin{array}{l}\text { (1)知る権利はない } \\
\text { (3)自分の榷利を等るため知る権利が } \\
\text { ある }\end{array}$ & $\begin{array}{l}\text { (2)プライバシーから知る権利はない } \\
\text { (4)当然知る権利がある }\end{array}$ \\
\hline
\end{tabular}


在が報告されている（相沢ほか，1996；Kitaura et al., 1997).この様な意識が生ずる原因のひと つに学生時代の教育の不十分さが指摘されてお り，現在行われている教育の中にエイズに関する 内容を追加したり, 再教育を行う必要性があると 報告されている（Tolle-Watts and Shuman, 1991 ; Rankin et al., 1993 ; Snyder, 1993 ; 廣 瀬ほか，2000）。実際にエイズ教育を試み，意識 の向上を図った報告（岡田ほか，1994; 薩田ほ か, 1997 ; 黒木・高柳, 1997 ; 石津ほか, 2000a) もあるが，具体的に教育効果があがり意識や知識 が持続する教育方法が確立されているとは言えな
い. 本研究では意識・知識をより向上させるため には系統的・継続的にエイズ教育を実施する必要 があると考え，歯科衛生士専門学校生を対象に基 礎講義時間内に 1 年間系統立てたエイズに関する 講義の実施を試み，生徒の意識がどのように変化 したかを調查した。

$$
\text { 川方法 }
$$

1999 年 4 月に東海地区の 3 つの歯科衛生士専門 学校に入学した女子 158 名 (A校 53 名, B校 56 名, C 校 49名）に対し，エイズに関する意識調查を 実施した。調査は各学校とも入学時の 4 月の初め

表 2 エイズに関する知識の質問内容

\begin{tabular}{|c|c|c|c|c|c|}
\hline \multicolumn{6}{|c|}{ ウイルスに関する項目 } \\
\hline Q17 & エイズを引き起こすウイルスは & (1) HIV & (2) $\mathrm{HBV}$ & (3) $\mathrm{HCV}$ & (4) HTLV-1 \\
\hline \multicolumn{6}{|c|}{ 疫学に関する項目 } \\
\hline $\begin{array}{l}\text { Q18 } \\
\text { Q19 } \\
\text { Q20 } \\
\text { Q21 }\end{array}$ & $\begin{array}{l}\text { HIV/AIDS が最も多い地域は } \\
\text { HIV/AIDS が急増している地域は } \\
\text { 日本の感染原因で最も多いのは } \\
\text { エイズの感染原因で最も多いのは }\end{array}$ & $\begin{array}{l}\text { (1)アメリカ州 } \\
\text { (1)南アメリカ } \\
\text { (1)同性間性的接触 } \\
\text { (1)輸血 }\end{array}$ & 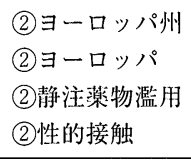 & $\begin{array}{l}\text { (3)アフリカ州 } \\
\text { (3)南アフリカ } \\
\text { (3)凝固因子製剤 } \\
\text { (3)母子感染 }\end{array}$ & $\begin{array}{l}\text { (4)オセアニア州 } \\
\text { (4)オセアニア } \\
\text { (4)母子感染 } \\
\text { (4)静注薬物濫用 }\end{array}$ \\
\hline \multicolumn{6}{|c|}{ 感染に関する項目 } \\
\hline $\begin{array}{l}\text { Q22 } \\
\text { Q23 }\end{array}$ & $\begin{array}{l}\text { ウイルスが体内で結合するのは } \\
\text { 感染を介在する程度のウイルスが } \\
\text { 存在するのは(MA) } \\
\text { 感染効率が最も高いのは }\end{array}$ & $\begin{array}{l}\text { (1)赤血球 } \\
\text { (1)唾液 } \\
\text { (5)尿 } \\
\text { (1)輸血 }\end{array}$ & $\begin{array}{l}\text { (2) B リンパ球 } \\
\text { (2)鼻汁 } \\
\text { (6)胵分泌液 } \\
\text { (2)性的接触 }\end{array}$ & $\begin{array}{l}\text { (3)好中球 } \\
\text { (3)精液 } \\
\text { (7)母乳 } \\
\text { (3)舟子感染 }\end{array}$ & $\begin{array}{l}\text { (4) } \mathrm{T}_{4} \text { リンパ球 } \\
\text { (4)汗 } \\
\text { (8)涋 } \\
\text { (4)静注薬物濫.用 }\end{array}$ \\
\hline \multicolumn{6}{|c|}{ 症状に関する項目 } \\
\hline $\begin{array}{l}\text { Q25 } \\
\text { Q26 } \\
\text { Q27 } \\
\text { Q28 }\end{array}$ & $\begin{array}{l}\text { 感染すると影響するものは } \\
\text { 感染してから発症までの期間は } \\
\text { 発生した時症状として出ないのは } \\
\text { エイズ患者の口腔に現れる症状は }\end{array}$ & $\begin{array}{l}\text { (1)遺伝子 } \\
\text { (1) } 3 \sim 4 \text { 週間 } \\
\text { (1)カリニ肺炎 } \\
\text { (1) 白板症 }\end{array}$ & $\begin{array}{l}\text { (2)免疫 } \\
\text { (2) } 2 \sim 3 \text { カ } \\
\text { (2)カンジダ症 } \\
\text { (2)ガマ腫 }\end{array}$ & $\begin{array}{l}\text { (3)リンパ液 } \\
\text { (3)半年〜 } 1 \text { 年 } \\
\text { (3)脳症 } \\
\text { (3)エプーリス }\end{array}$ & $\begin{array}{l}\text { (4)造血機能 } \\
\text { (4) } 3 \sim 10 \text { 年 } \\
\text { (4) 肺がん } \\
\text { (4)う蝕 }\end{array}$ \\
\hline \multicolumn{6}{|c|}{ 検查に関する項目 } \\
\hline $\begin{array}{l}\text { Q29 } \\
\text { Q30 }\end{array}$ & $\begin{array}{l}\text { エイズ検査の媒体は } \\
\text { 感染後に検查が陽性となるのは } \\
\text { どれくらい経ってからか }\end{array}$ & $\begin{array}{l}\text { (1) 尿 } \\
\text { (1)直後 }\end{array}$ & $\begin{array}{l}\text { (2)血液 } \\
\text { (2) } 1 \text { 週問後 }\end{array}$ & $\begin{array}{l}\text { (3)大便 } \\
\text { (3) } 2 \text { 力月後 }\end{array}$ & $\begin{array}{l}\text { (4) 皮豦 } \\
\text { (4) } 1 \text { 年後 }\end{array}$ \\
\hline Q31 & $\begin{array}{l}\text { エイズの届出内容に含まれない } \\
\text { ものは }\end{array}$ & (1)名前 & (2)性別 & (3)年齢 & (4)感染原因 \\
\hline \multicolumn{6}{|c|}{ 対策に関する項目 } \\
\hline Q32 & 現在のエイズの治療法は & (1)ワクチンの使用 & $\begin{array}{l}\text { (2)ウイルスの } \\
\text { 増殖を防ぐ }\end{array}$ & $\begin{array}{l}\text { (3)薬によるウイルス } \\
\text { の殺滅 }\end{array}$ & (4)骨髄移植 \\
\hline Q33 & 予防法として適切なのは & (1)抗生物質の使用 & (2)ピルの使用 & (3)コンドームの使用 & (4)身体をよく洗う \\
\hline Q34 & 感染の可能性が最も高い行為は & (1)スケーリング & (2)器具洗争 & $\begin{array}{l}\text { (3)バキュームによる } \\
\text { 吸引 }\end{array}$ & $\begin{array}{l}\text { (4)使用した注射針 } \\
\text { で指を刺す }\end{array}$ \\
\hline Q35 & ウイルスに有効な消毒薬は & (1)ある & (2)開発中 & (3)ない & \\
\hline
\end{tabular}


と臨床実習開始前の 1 年 2 月に講義時間を利用し, 無記名の自記式質問票を用いて行った。調查時に はそのつど生徒にエイズに関する認識を調べたい 旨を伝え，科目の成績とは無関係であること，自 由意志のため必ずしも回答する義務はないことを 伝えた。調查項目はフェイス・シートとエイズに 関する意識 16 項目 (一般生活上の意識 7 項目, 歯 科業務上の意識 9 項目), 知識 19 項目から構成さ れており，それぞれ四者択一あるいは複数回答と した（表 $1 ， 2$ ）。な扮各調查時点間の比較はフェ イス・シート上の生年月日より対応させて行っ

表 3 講義内容と講義実施時期

\begin{tabular}{lll}
\hline & 講義時期 & \multicolumn{1}{c}{ 講義内容 } \\
\hline 1 回目 & 1 年 4 月 & エイズの感染方法と尒防法について \\
2 回目 & 1 年 5 月 & エイズと人権閖題 \\
3 回目 & 1 年10月 & 抗 HIV 療法 \\
4 回目 & 1 年11月 & $\begin{array}{l}\text { 歯科医療従事者としてのエイズへの } \\
\text { かかわり }\end{array}$ \\
\hline
\end{tabular}

た。また $\mathrm{A}$ 校と $\mathrm{B}$ 校に関しては $4 ， 5 ， 10 ， 11$ 月 の計 4 回（1回90分）にわたり講義形式のエイズ 教育を行った（表3）。一方C 校に関しては教科 以外に特別な教育は行わなかった.

質問票の意識項目については選択肢を順序づ $け, 2$ 回の調査における選択の変化について平均 値の差の検定を用いて評価した．知識項目につい ては正答数の増加量について検討し, 正答率につ いては正規分布による母比率ならびに $\mathrm{t}$ 分布によ

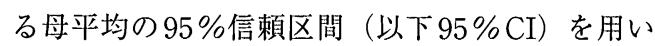
た.

なお本研究では 1,2 回目の調査ともに参加し た A 校 51 名, B校 49 名（以下講義群）とC校 45 名（以下無講義群）を対象に分析を行った.

\section{III 成 績}

1. エイズに関する一般生活上の意識について 一般生活上の意識は 2 回の調査で,講義群は Q2,

表 4 項目別の意識変化

一般生活上の意識

\begin{tabular}{|c|c|c|c|c|c|c|}
\hline & \multicolumn{3}{|c|}{ 講義群 } & \multicolumn{3}{|c|}{ 無講義群 } \\
\hline & 1 回目 & 2 回目 & $\mathrm{P}$ 值 & 1 回目 & 2 回目 & $\mathrm{P}$ 值 \\
\hline Q1 & $2.49 \pm 0.56$ & $2.43 \pm 0.50$ & 0.222 & $2.47 \pm 0.50$ & $2.51 \pm 0.59$ & 0.643 \\
\hline Q2 & $2.68 \pm 0.53$ & $2.91 \pm 0.47$ & 0.001 & $2.73 \pm 0.62$ & $2.82 \pm 0.49$ & 0.253 \\
\hline Q3 & $2.66 \pm 0.78$ & $2.35 \pm 0.73$ & 0.000 & $2.60 \pm 0.78$ & $2.33 \pm 0.74$ & 0.017 \\
\hline Q4 & $3.28 \pm 0.96$ & $3.38 \pm 0.94$ & 0.320 & $3.29 \pm 0.84$ & $3.38 \pm 0.91$ & 0.599 \\
\hline Q5 & $3.05 \pm 0.67$ & $3.05 \pm 0.67$ & 1.000 & $3.00 \pm 0.37$ & $3.13 \pm 0.46$ & 0.057 \\
\hline Q6 & $2.46 \pm 0.69$ & $2.87 \pm 0.58$ & 0.000 & $2.60 \pm 0.58$ & $2.93 \pm 0.65$ & 0.003 \\
\hline Q7 & $2.80 \pm 0.68$ & $2.89 \pm 0.62$ & 0.243 & $2.62 \pm 0.61$ & $3.00 \pm 0.64$ & 0.001 \\
\hline \multicolumn{7}{|c|}{ 歯科業務上の意識 } \\
\hline & \multicolumn{3}{|c|}{ 講義群 } & \multicolumn{3}{|c|}{ 無講義群 } \\
\hline & 1 回目 & 2 回目 & $\mathrm{P}$ 值 & 1 回目 & 2 回目 & $\mathrm{P}$ 值 \\
\hline Q8 & $2.64 \pm 0.77$ & $2.08 \pm 0.65$ & 0.000 & $2.67 \pm 0.67$ & $2.24 \pm 0.65$ & 0.001 \\
\hline Q9 & $2.80 \pm 0.65$ & $3.09 \pm 0.57$ & 0.000 & $2.84 \pm 0.52$ & $3.13 \pm 0.59$ & 0.008 \\
\hline Q10 & $2.83 \pm 0.60$ & $2.67 \pm 0.67$ & 0.009 & $2.62 \pm 0.61$ & $2.42 \pm 0.54$ & 0.037 \\
\hline Q11 & $3.15 \pm 0.64$ & $3.11 \pm 0.62$ & 0.574 & $3.02 \pm 0.69$ & $2.91 \pm 0.60$ & 0.359 \\
\hline Q12 & $2.81 \pm 0.58$ & $2.75 \pm 0.66$ & 0.379 & $2.69 \pm 0.63$ & $2.69 \pm 0.63$ & 1.000 \\
\hline Q13 & $2.64 \pm 0.69$ & $2.76 \pm 0.57$ & 0.128 & $2.71 \pm 0.55$ & $2.73 \pm 0.62$ & 0.830 \\
\hline Q14 & $2.59 \pm 0.91$ & $2.84 \pm 0.86$ & 0.016 & $2.31 \pm 0.95$ & $2.20 \pm 0.87$ & 0.375 \\
\hline Q15 & $2.95 \pm 0.69$ & $3.41 \pm 0.59$ & 0.000 & $3.00 \pm 0.52$ & $3.24 \pm 0.91$ & 0.109 \\
\hline Q16 & $2.81 \pm 0.95$ & $2.94 \pm 0.98$ & 0.254 & $3.02 \pm 0.89$ & $3.22 \pm 0.95$ & 0.152 \\
\hline
\end{tabular}


表 5 項目別の正答率と 95\% 信頼区間

\begin{tabular}{|c|c|c|c|c|c|c|c|c|}
\hline & \multicolumn{4}{|c|}{ 講義群 } & \multicolumn{4}{|c|}{ 無講義群 } \\
\hline & & 1 回目 & & 2 回目 & & 1 回目 & & 2 回目 \\
\hline Q17 & 99.0 & {$[94.6,99.8]$} & 98.0 & {$[93.0,99.4]$} & 100 & {$[93.6,100]$} & 100 & {$[93.6,100]$} \\
\hline Q18 & 18.0 & {$[11.7,26.7]$} & 32.0 & {$[23.7,41.7]$} & 26.7 & {$[16.0,41.0]$} & 35.6 & {$[23.2,50.2]$} \\
\hline Q19 & 13.0 & {$[7.8,21.0]$} & 33.0 & {$[24.6,42.7]$} & 28.9 & {$[17.7,43.4]$} & 46.7 & {$[32.9,60.9]$} \\
\hline Q20 & 17.0 & {$[10.9,25.5]$} & 21.0 & {$[14.2,30.0]$} & 33.3 & {$[21.4,47.9]$} & 33.3 & {$[21.4,47.9]$} \\
\hline Q21 & 76.0 & {$[66.8,83.3]$} & 74.0 & {$[64.6,81.6]$} & 75.6 & {$[61.3,85.8]$} & 66.7 & {$[52.1,78.6]$} \\
\hline Q22 & 3.0 & {$[1.0,8.5]$} & 16.0 & {$[10.1,24.4]$} & 15.6 & {$[7.7,28.8]$} & 11.1 & {$[4.8,23.5]$} \\
\hline Q23 & 41.0 & {$[31.9,50.8]$} & 44.0 & {$[34.7,53.8]$} & 26.7 & {$[16.0,41.0]$} & 35.6 & {$[23.2,50.2]$} \\
\hline Q24 & 41.0 & {$[31.9,50.8]$} & 40.0 & {$[30.9,49.8]$} & 42.2 & {$[29.0,56.7]$} & 46.7 & {$[32.9,60.9]$} \\
\hline Q25 & 72.0 & {$[62.5,79.9]$} & 82.0 & {$[73.3,88.3]$} & 95.6 & {$[85.2,98.8]$} & 82.2 & {$[68.7,90.7]$} \\
\hline Q26 & 69.0 & {$[59.4,77.2]$} & 69.0 & {$[59.4,77.2]$} & 68.9 & {$[54.3,80.5]$} & 75.6 & {$[61.3,85.8]$} \\
\hline Q27 & 45.0 & {$[35.6,54.8]$} & 48.0 & {$[38.5,57.7]$} & 46.7 & {$[32.9,60.9]$} & 51.1 & {$[37.0,65.0]$} \\
\hline Q28 & 40.0 & {$[30.9,49.8]$} & 59.0 & {$[49.2,68.1]$} & 37.8 & {$[25.1,52.4]$} & 53.3 & {$[39.1,67.1]$} \\
\hline Q29 & 97.0 & {$[91.5,99.0]$} & 99.0 & {$[94.6,99.8]$} & 100 & {$[93.6,100]$} & 97.8 & {$[88.4,99.6]$} \\
\hline Q30 & 29.0 & {$[21.0,38.5]$} & 46.0 & {$[36.6,55.7]$} & 57.8 & {$[43.3,71.0]$} & 64.4 & {$[49.8,76.8]$} \\
\hline Q31 & 72.0 & {$[62.5,79.9]$} & 72.0 & {$[62.5,79.9]$} & 84.4 & {$[71.2,92.3]$} & 84.4 & {$[71.2,92.3]$} \\
\hline Q32 & 49.0 & {$[39.4,58.7]$} & 46.0 & {$[36.6,55.7]$} & 53.3 & {$[39.1,67.1]$} & 64.4 & {$[49.8,76.8]$} \\
\hline Q33 & 93.0 & {$[86.3,96.6]$} & 93.0 & {$[86.3,96.6]$} & 84.4 & {$[71.2,92.3]$} & 86.7 & {$[73.8,93.7]$} \\
\hline Q34 & 93.0 & {$[86.3,96.6]$} & 93.0 & {$[86.3,96.6]$} & 93.3 & {$[82.1,97.7]$} & 88.9 & {$[76.5,95.2]$} \\
\hline Q35 & 9.0 & {$[4.8,16.2]$} & 34.0 & {$[25.5,43.7]$} & 13.3 & {$[6.3,26.2]$} & 17.8 & {$[9.3,31.3]$} \\
\hline 平均 & 51.4 & {$[36.0,66.8]$} & 57.8 & {$[45.0,70.7]$} & 57.1 & {$[42.7,71.5]$} & 60.1 & {$[47.4,72.8]$} \\
\hline
\end{tabular}

Q3，Q6の3項目に意識の変化が認められた。Q2 では日本での流行を危惧し，Q3では一般生活で の感染不安を持ち，またQ6ではエイズ検査を受 ける選択肢を回答した学生が増加した，無講義群 では Q3, Q6, Q7に変化が認められ, 講義群と同 様に一般生活での感染を危惧し，エイズ検査を受 けると回答した者が増加した。また一般生活上の 感染予防知識を持つと答えた者も増加した（表4).

\section{2. エイズに関する歯科業務上の意識について}

講義群では 5 項目に意識の変化が認められ, Q8では歯科治療に携わる時に感染することがあ ると考え，Q10ではHIV/AIDSが来院してきて も対応する場合には意識すると回答する者が増加 するなど，消極的な意見を持つことが示された． 一方 Q9 ではHIV/AIDSの歯科治療に携わる可能 性を認め，Q14より歯科医師や衛生士がエイズに 感染していても歯科業務を行ってよいと答え,
Q15では患者が感染しているかを知る必要がある と答えた者が増加した，無講義群では3 項目で意 識が変化し，講義群と同様にQ8，9，10に差が 認められた（表4）.

\section{3. エイズに関する知識調査について}

講義群は平均正答率が 1 回目に $51.4 \%, 2$ 回目 $57.8 \%$ と 2 回目に増加し, 特にQ19, Q22, Q35 の 3 項目では統計的に有意に正答率の増加が見ら れた。無講義群では 1 回目の平均正答率が $57.1 \%$ と講義群と比較して知識が高いことが認められた が, 2 回目には $60.1 \%$ とわずかな増加にとどまっ た（表 5). 正答数の増加量で見ると講義群で はー7問から 9 問，無講義群では -4 問から 4 問に 分布しており, 平均正答数増加量はそれぞれ 1.23 [0.77, 1.69] 問, $0.58[-0.0004,1.16]$ 問であ った (図 1 ). 

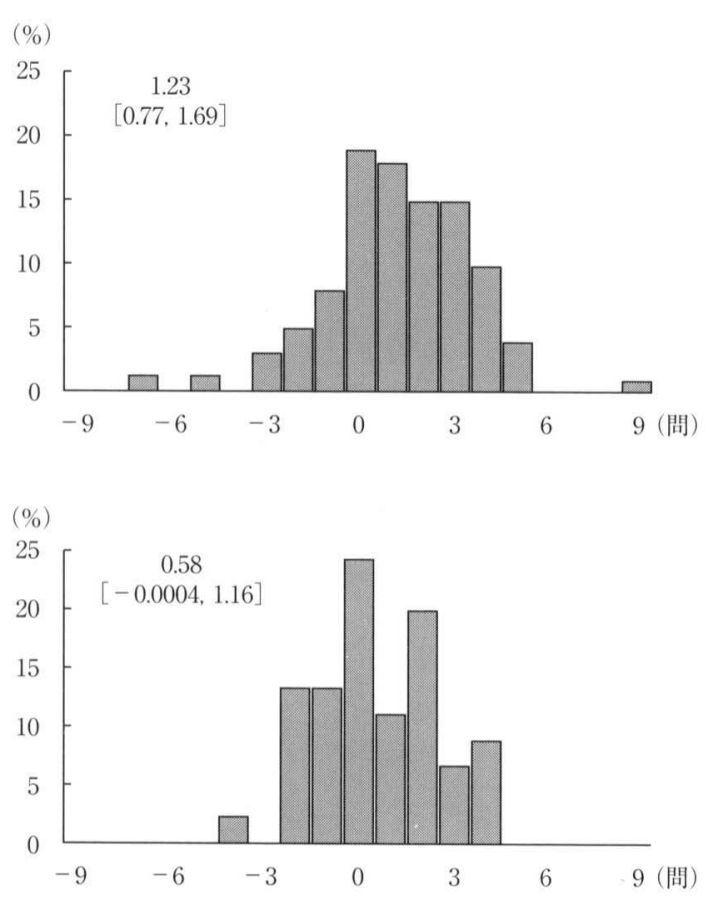

図1 エイズに関する知識の増加量と $95 \%$ 信頼区間

上段：講義群, 下段：無講義群

\section{IV 考察}

エイズが国際的な感染症として認識されて約 20 年が経過するが，いまだにエイズは完治しな い疾病であり,ごく一部の感染原因により多くの 偏見や差別が存在する。これは歯科医療従事者あ るいはその学生においても同様で, HIV/AIDS の歯科治療に消極的あるいは診療拒否を容認する 傾向があると報告されている（相沢ほか, 1996 ; Kitaura et al., 1997)。我々は1997年より 歯学部学生および歯科衛生士専門学校生を対象に エイズに関する意識調查を実施してきた。その結 果両学生ともエイズに関して十分な意識および知 識を携えて掞らず, 不十分な意識の状態で卒業し, 臨床の現場に出ていることが認められた（廣瀬ほ か, 1997 ; 小澤ほか, 1998 ; 石津ほか, 1998). 一方エイズに関する知識と意識の関連は重要であ り, 知識量の増加が差別や偏見の払拭や意識の向
上には結びつかないという報告（橋爪ほか， 1995 ；原田ほか，1997）もあれば, 正しい知識 を持つことや感染予防法を確実に実践できれば受 容的な態度が高まり, HIV/AIDSをより身近な こととして捕らえることが可能になるという報告 (Shafer and Boyer, 1991 ; Rankin et al., 1993 ; Horst, 1993 ; 岡田ほか, 1994 ; 石津ほ か, 2000b）もある。歯科衛生士を含菊科医療 従事者は偏見や差別意識を持つことなしに HIV/AIDSの歯科治療を行わなければならない. そのためには教育の重要性が強調されており, そ の内容としては現行のカリキュラムにエイズに関 することを取り入れること, 学習時期に合わせ系 統的な教育を行うこと, 新しく正確な情報を伝え ること，不安を払拭させることなどがあげられる (Gary, 1988 ; Currey et al., 1990 ; TolleWatts and Shuman, 1991 ; Snyder, 1993 ; Rankin et al., 1993 ; 廣瀬ほか, 2000)。そこで 
本研究では歯科衛生士専門学校生を対象に入学時 から 4 回にわたり講義形式のエイズ教育を実施 し，教育による意識の変化について検討した。講 義内容は 1 回目はエイズの一般的な知識と予防法 や疫学的内容について, 2 回目は人権問題や倫理, 告知などについて, 3 回目はHIV/AIDSの生活や 服薬をはじめ抗 HIV 療法について，そして最終 回はスライドを用いて歯科医療従事者としてのエ イズへのかかわりやHIV/AIDSの口腔内症状に ついて講義を実施した（表3）。すなわち $1 \cdot 2$ 回 目の講義はエイズに関する基本的な内容や倫理観 など入学早期に理解しておくべき内容とし，3・ 4 回目の講義は医学的知識が十分でないと理解で きない内容を含むものとした。な㧍講義群の分析 対象者はすべての者が4回の講義を受けている.

1 回目の調査では一般生活上の意識と蒾科業務 上の意識ですべての項目に講義群と無講義群との あいだに意識の差は認められなかった。一般生活 上の意識項目については 2 回目の調査で講義群, 無講義群ともにQ3 と Q6 に関して意識が変化し ており，一般生活で感染する不安を持つ者が増加 し，エイズ検查を受けようと積極的な姿勢を示す 者が増加するなど，エイズという病気を身近に感 ずるようになっていた．講義群では Q2において も意識に変化を認め, 日本でのエイズ流行を危惧 する回答が多かった（表4）。無講義群でも一般 生活上の意識が変化した項目が存在したが，これ はエイズに関する調查を実施したことで，ある程 度はエイズという疾病について考えるようにな り，その結果が意識の変化につながったものと考 えられる。

歯科業務上の意識については両群とも $\mathrm{Q} 8, \mathrm{Q} 9$, Q10において意識が変化し, HIV/AIDSの柬科治 療に携わる可能性を示唆し, その際には意識して 治療に携わり，感染する可能性があると考える者 が増加した（表4）. 歯科処置は一般に観血的処 置が多く, 感染を媒介する血液や体液, 唾液など の暴露が多いものの, 歯科医療従事者の職業上の HIV 感染率は非常に低いと言われている（Dobluog et al., 1988 ; Scully and Porter, 1991). 相
沢ほか（1996）は歯科医療従事者がHIV/AIDS の歯科治療に積極的でない理由として感染者の歯 科治療が安全ではないこと, 適切な感染予防の訓 練を受けていない者が多いことをあげている．医 療従事者のエイズに対する無知や誤った知識は, 患者の受け入れに支障をきたしたり，感染者への 差別につながる．また極端に偏った認識は将来， 医療従事者の減少や診療拒否というかたちで表れ る危険性も考えられる。山口ほか（2000）は HIV/AIDSの歯科治療は基本的な standard precautionを行えば一般の歯科医でも安全な治療が 可能であると述べている．針刺しや切創事故など 感染の可能性のある部分も存在することを生徒に 意識させる必要はあるが, HBV 感染予防対策が 行われていればHIV を特別に警戒する必要はな い.

講義群ではQ15において歯科医療従事者は患 者がエイズに感染しているかを知る必要があると 回答する者が有意に増加した. Horst G et al. （1989）はアムステルダムの歯科医師を対象に実 施した調查で, 半数近くの者は患者からの感染を 予防するために患者が HIV 感染者か否かを知る 必要があると回答したと報告している，歯科医療 従事者が患者がエイズに感染しているかを知る必 要がある理由としては，そのHIV/AIDSの病状 にあった菌科治療を行ったり歯科疾患の予防や進 行阻止のためと考えられる。

エイズに関する知識項目では調查開始時の 1 回 目に無講義群で知識が高いことが認められた（表 5). 2 回目の調査では講義群で正答数の増加が認 められたが, 無講義群では変わらなかった (図 1). 項目別に見た場合，雨群とも疫学に関する項目， 感染に関する項目で正答率が低い傾向にあった. また講義群では無講義群に比較して両調査時点で 疫学に関する項目や検查に関する項目で正答率が 低い傾向にあったここれは対象となった学校環境 の相違が原因と考えられる。講義群のうち $\mathrm{A}$ 校 は敷地内に病院が設置されているもののエイズに 関する情報が入手しやすい環境とは言い難い．ま たB校は周辺に病院や保健所などは存在せず単独 
で設置されている学校である。一方無講義群のC 校は敷地内に保健所や看護学校が隣接しており, 他の 2 校と比べるとエイズに関する情報が入手し やすい環境である。事実 1 回目の調查を実施した 後に保健所でエイズ検查を行った者も数名存在 し，受検時になんらかのエイズに関する情報を得 たものと考えられる.

今回はエイズのみについて講義を行ったが, 講 義を実施することによりその病気への差別心や新 たな恐怖心が生まれることも考えられるため，工 イズに限った講義を実施するのではなく，広い視 野から感染症のひとつとして講義を実施していく べきと考えられる．現行の歯科衛生士教育は 2 年 制であり，そのカリキュラムは過密であるため新 しい分野を教育内容に組み込むには多くの困難が ある，今回このような中，4回の講義を組み込ん だものの，多くのエイズに関する情報を伝達する には少なからず無理があったのも事実である。今 後は他の科目と連携を取り, 限られた洔間内に効 率よく教育できる方法を検討することが必要であ ると考えられる。

今回 4 回の系統的・継続的なエイズ教育を実施 した結果，エイズを身近に感じるようになり，知 識が増加することが示された. 今後はこれらの意 識や知識が身についているか否かを追跡調査して いくことが必要であり, 同時に 2 年時は臨床箺習 が主体となるため実習内容をふまえたエイズ教育 を奏施していく必要性があると考えられる.

\section{V 結 論}

蒾科衛生士専門学校生に対し系統的・継続的な エイズ教育を実施した時のエイズに関する意識の 変化を検討した. その結果講義群, 無講義群とも 意識に変化が見られ，エイズを身近に感ずる生徒 が増加した。ささらに講義群では一般生活上の意識 項目においてエイズの流行を危惧すると回答する 者が增加し，また歯科業務上の意識については感 染時に歯科業務を行ってもよいと考え，患者が感 染しているかを知る必要があると回答する者が増 加した，エイズに関する知識については教育後に
增加が認められた．今後は本教育の効果が継続的 に身についているかを追跡調查する必要性がある と考えられる.

\section{文献}

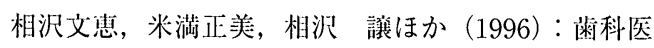
師の感染予防対策とエイズに阅する知識と態度, 目 本公衛誌，43(5)，364-373

Currey CJ, Johnson M, Ogden B (1990): Willingness of health-professions students to treat patients with AIDS, Acad. Med., 65(7), 472-474

Dobloug JH, Gerner NW, Hurlen B et al., (1988): HIV and hepatitis B infection in an international cohort of dental hygienists, Scan. J. Dent. Res., 96(5), 448456

Gary CJ (1988): AIDS in dental education, J. Law Ethics Dent., 1(4), 211-214

原田江梨子, 道重文子, 多田炤栄ほか（1997）：看護 学生のエイズに関する知識㧍よび態度一学年進行に ともなう変容について一, 德島大医短紀要, 7 , $59-71$

橋爪永子，村鸣正幸，河原宣子ほか（1995）：三重県 の看護婦におけるエイズに関する知識と態度の変 化, 日本公衛誌, 42(12)，1054-1060

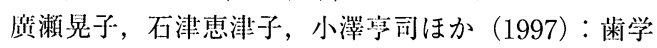
部学生のエイズに阅する知識調查, 日茵医潦管理誌, $32(2), 135-143$

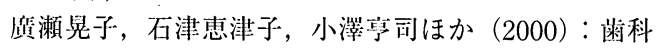
衛生士学校生の AIDSに関する意識の追跡調查, 民 族衛生, 66(6), 229-239

Horst G, Hammann-Konings G, Maritz BM et al., (1989): AIDS and infection control. Amsterdam dentists surveyed, J. Publish Health Dent., 49, 201205

Horst G (1993): AIDS and infection control: Dutch dental hygienists surveyed, Community Dent. Oral Epidemiol., 21(2), 86-90

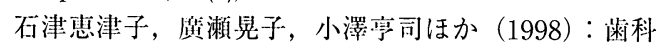
街生士臨床实習生のAIDSに関する意識, 口腔衛生 会誌, 48(3)，244-251

石津恵津子, 廣瀨晃子, 小澤亭司ほか（2000a）： AIDS教育を行った窲科衛生士尃門学校卒業生の意

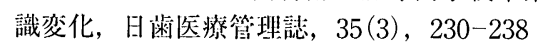

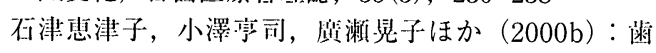
科街生士学校生の HIV/AIDSに対する意識の解析, 民族衛生，66(5)，190-201

Kitaura H, Adachi N, Kobayashi K et al., (1997): Knowledge and attitudes of Japanese dental health care workers towards HIV-related disease, J. Dent., 
25(3), 279-283

黒木淳子, 高柳和江 (1997) : エイズ・ピア・エデュ ケーションの教育効果, 医学教育, 28(2), 101106

茂木伸夫, 小林信之, 千葉 緑 (2000)：HIV 感染者 の実態と対応，歯界展望，96(5)，1167-1172

岡田耕輔, 小寺良成, 安田誠史ほか（1994）：看護学 生の持つHIV/AIDSに関する知識と意識・態度と の関連，日本公衛誌，41(6)，538-547

小澤亨司，廣瀬晃子，石津恵津子ほか（1998）：歯学 部学生のエイズに関する意識調査, 日歯医療管理誌, $32(3), 198-210$

Rankin KV, Jones DL, Rees TD (1993): Attitudes of dental practitioners and dental students towards AIDS patients and infection control, Am. J. Dent., 6 (1), $22-26$

薩田清明，今中正美，道本千衣子ほか（1997）：看護 婦のAIDSに対する意識と知識について一AIDS教 育受講群と非受講群の比較から一, 東京家政学院大 学紀要, 37, 233-239
Scully C, Porter S (1991): The level of risk of transmission of human immunodeficiency virus between patients and dental staff, Br. Dent. J., 170(2), 97-100

Shafer MA, Boyer CB (1991): Psychosocial and behavioral factors associated with risk of sexually transmitted diseases, including human immuno-deficiency virus infection, among urban high school students, J. Pediatr., 119(5), 826-833.

Snyder GA (1993): Pennsylvania dental hygienist's knowledge, attitude, and infection control practices in relation to AIDS and AIDS patients, J. Dent. Hyg., 67(4), 188-196

Tolle-Watts SL, Shuman D (1991): AIDS education in dental hygiene programs in the United States and Canada, J. Dent. Hyg., 65(3), 124-129

山口 泰, 前川理人，玉木祐介ほか（2000）：国立仙 台病院における HIV 感染者の歯科治療, 東北大歯 誌, 19(1), 33-36

(受稿 2002.3. 20 ；受理 2003. 1. 31) 